\title{
THE FUNCTIONING OF SMART CITY IN THE CONTEXT OF GLOBAL CITY RANKINGS
}

\author{
Barbara ROŻAŁOWSKA \\ Silesian University of Technology; barbara.rozalowska@polsl.pl, ORCID: 0000-0003-3455-1073
}

Purpose: This paper raises theoretical issues related to the functioning of cities that are determined as smart in order to find a better operational definition for further research.

Design/methodology/approach: In search of the essence of the term, the paper refers to variety of definitions of smart city, and also to the theoretical models in operation enabling the measurement and comparison of indicators among urban areas in the different world locations. The analysis was performed on three rankings: Cities in Motion Index, Mercer Quality of Living, Arcadis The Sustainable Index.

Findings: The conclusions indicate that the Smart City concept is connected with sustainable development more than to the quality of life. The city rankings concerning the highest life quality is completely different from the hierarchy of smart cities.

Originality/value: The paper extends the definition of smart city and it may be valuable for researchers who develop the concept of smart city in their research.

Keywords: smart city, sustainable development, quality of life, benchmarking cities.

Category of the paper: General review.

\section{Introduction}

The 21 st century will certainly be the age of cities. The WHO estimates that, no later than 50 years into the century, most people will live in cities (WHO, 2013). It will help reduce the extent of rural poverty in less developed countries. At the same time, urban space will face a challenge of ensuring best life conditions possible to huge populations, reaching almost 20 million people in some cases. From the very beginning, the smart city concept, having arisen in the late 1980s, was a suggestion to enhance the potential of cities by the Information and Communication Technology in order to sustain technological development and competitive advantage of cities (Komninos, 2018). The current approach to the smart city concept includes not only the traditional technical aspects, but also social or environmental factors more and more often (Höjer, and Wangel, 2015). There is no consent what should be the development 
index for such cities: saturation with technology, the quality of life or, perhaps, a positive effect of the urban ecosystem balancing.

The rivalry between the cities to gain the influence on domestic, regional or global level was previously described by researchers of the metropolisation processes. Smart city is not a synonym for "metropolis". Unlike metropolisation, the smart city concept is rarely considered in a wider context, regional or national. One can notice, though, that the cities that have implemented development strategies using ICT more often become a model to be followed, as they influence the preferred development directions in urbanised areas (smartcitypoland.com/...). Smart city may be a minor town, as in the case of Milton Keynes, England, that competes for the position of the smartest city with other places leading the way in the United Kingdom (Cowley, Joss, and Dayot, 2018).

This article presents an overview of the smart city concepts, collated with various theoretical models applied by researchers to elucidate the essence of transformations experienced in modern cities. Furthermore, it raises the topic of comparison of city development and measurement of the extent of its development, also including "smartness", using rankings created by researchers. The objective of the paper is to analyse the structure of smart city indexes, and to present the most relevant factors affecting the rank of certain urban centre, using cities leading the rankings as examples. In this paper, the regional development was used to illustrate global rivalry existing among the cities worldwide these days.

\section{Research perspective, theoretical framework and methods}

This paper is based on theoretical analysis of the most frequently cited papers, looked up in electronic resources of scientific publications available in the Google Scholar browser, with the "smart city" and "intelligent city" keywords used as search phrases. This presentation of the topics bases on targeted selection in order to fulfil the assumption of showing the most varied views in the publications concerning this issue. The primary objective, as specified during the analysis, is to define central aspects responsible for the structure of the "smart city" phrase as well as its implications, used in the course of creation of any urban area development index. According to various authors, the implementation of smart solutions correlates with social development, improvement in the functioning of city technical systems and with management improvement. The effects of such changes entail a raise in the aggregated indexes regarding quality of life and improvement in the environment condition. Local and regional development is therefore driven by innovations implemented in a smart city. The relationships which occur are demonstrated by theoretical models outlined by researchers: Quadruple Helix Model and Penta Helix (Calzada, and Cowie, 2017) which, in order to be able to emerge, require public-private partnership, academia, and civic institutions. The development indexes, resulting 
directly from the operational definitions of the smart city, and theoretical models of innovation in urbanised regions are used in multiple configurations to build the tools to measure and to compare cities. The development of such tools has been supported by the EU Framework Programme, Horizon 2020 (H2020-SCC-2016/2017), and by private consulting companies interested in city benchmarking (Mercer, 2019).

To present the differences in city development comparison, the research method of the analysis of existing data was adopted. The cyclical city rankings were used developed by the research platform, launched together by The Center for Globalization and Strategy in Barcelona and the Department of Strategy of IESE Business School University of Navarra (CIMI, 2019), and two other ones: Mercer Quality of Living and Acardic The Sustainable Cities Index.

\section{Results}

\subsection{Definition problems and theoretical models for the smart city development}

Since the beginning of the 21 st century, a lot of definitions of smart city has been established, highlighting the conceptual disagreement resulting from different research perspectives suggested by the different fields of science. Furthermore, this term is used interchangeably with numerous terms, such as digital city, ubiquitous city, wired city, information city, hybrid city, intelligent city (Dameri, 2017). The first definitions that affected the process of conceptualisation of smart city referred to a space with specific properties, and disregarded the characteristics of cities. These meant "territories with high capacity for learning and innovation, which is built-in the creativity of their population, their institutions of knowledge creation, and their digital infrastructure for communication and knowledge management" (Komninos, 2002, p. 1). Similarly, R.P. Dameri (2013) considers a smart city in the context of geographic region which uses modern information and communication technologies, logistics, power generation etc. to ensure measurable benefits to citizens. A measuring index may be welfare, integration, civic participation or environment quality. This space needs to be properly managed what will allow to determine the city's policy and development principles.

It should be noted that there are two differing views on the essence of modern cities: technical approach and social approach. A part of researchers only assigned the smart city concept to innovative technologies. The definitions from this point of view emphasise the role of "utilization of networked infrastructures to improve economic and political efficiency and enable socio, cultural and urban development" (Hollands, 2008, p. 307). They point out to the ICT's superiority over citizens, environment or smart development. In this case, the city development should be measured by analysing the scale of IT solutions, urban infrastructure 
monitoring performance indexes, and system integration methods (Orłowski, 2014). However, another group of researchers sees an enormous development potential in citizens connected to the web, both online and offline. The vision of the cities, driven and controlled by bottom-up citizens-residents (Calzada, and Cobo, 2015) is one of the most suggested concepts these days. In this spirit, two Polish researchers, F. Kuźnik and M. Baron define the smart city as "a city that is co-created by behaviours of its residents and other users through information and communication technologies implemented systematically by local authorities and its public and private partners" (Kuźnik, and Baron, 2018, p. 64). The city development indexes are also sought out in actions undertaken by citizens, in the degree of their independence and their impact on city management (Cardullo, and Kitchin, 2019).

In the recent 15 years, the scientific debate on the roles of technical and social accelerators of smart city transformation displays significant variability. One can clearly see that technical factors are slowly being abandoned for the sake of social factors, and the neoliberal motifs for using technology in the city gain recognition. An approach, one of many, that depicts the evolution of smart city narration is the 3RC concept presented in the paper titled How do we understand smart cities? An evolutionary perspective. It describes four distinctive yet different ways for seeing the essence of the development of cities that have chosen the smart strategy, i.e. restrictive, reflective, rationalistic and critical (Kummithaa, and Crutzenb, 2017). The restrictive approach highlights the relevance of technology in the improvement of quality in municipal systems providing services to residents. The "quality of life" term, as referred to cities, is connected to performance and efficiency of the electric grid, the water supply and sewage system, and the transportation systems. Technology in the form of "the Internet of Things" (IoT) is a primary middle-man in contacts between service providers, citizens and municipal/government agencies. The reflective approach is typical for papers where residents emerge as the direct end users of technical solutions being offered. Technology is a mean for the development of human capital, creativity and improvement in the quality of life. In this context, the technical aspects of smart city are more important than the actions of citizens. The rationalistic approach, however, restores agency for residents, perceiving them as the change instigators, and their skills and knowledge as crucial to the city development. Technology is used to satisfy the existing needs, not to create new ones. More recent papers more and more frequently state that international corporations lobbying stands behind the promotion of the smart city concept (Kummithaa, and Crutzenb, 2017). The goal is neither to develop the urban community nor to improve system performance, but rather to form a "hightech variation of urban entrepreneurialism" (Holland, 2008).

There is a number of different proposals for defining smart city, however, the conceptual space that emerged in the wake of combination of different views of smart city implies that the purpose of the ICT is to make citizens more active, to solve problems better, and to improve the quality of life (Komninos, 2018). Smart city is more often connected to the sustainable development concept. Smart Sustainable City (SSC) combines two concepts: smartness and 
sustainability (Höjer, and Wangel, 2015). Technology in the city contributes to a raise in productivity and drives consumption, thus a need for actions aiming to restore the balance lost. The authors indicate how combinations of very different components effects in a balance necessary for the improvement in the quality of life, while highlighting the relevance of social participation. „A city to be smart when investments in human and social capital and traditional (transport) and modern (ICT) communication infrastructure fuel sustainable economic growth and a high quality of life, with a wise management of natural resources, through participatory governance" (Caragliu, and De Bo, and Nijcamp, 2009).

Smart city may be perceived in a wider context, as a property attributed to a modern, global society. ICT allows for establishment of hyper-connected societies, made primarily of the city residents, well-informed on technology and making use of the possibilities it provides (Calzada, and Cobo, 2015).

R. Giffinger and G. Haindlmaier (2010) suggested the widest operational definition of the smart city that may be used while researching the development level of a city/region. The conceptual space is based on six individual aspects: smart economy, smart people, smart governance, smart mobility, smart environment and smart living.

\section{Table 1.}

Dimensions of smart city

\begin{tabular}{|l|l|}
\hline Smart Economy (Competitiveness) & Smart People (Social and Human Capital) \\
\hline Innovative spirit & Level of qualification \\
Entrepreneurship & Affinity to lifelong learning \\
Economic image \& trademarks & Social and ethnic plurality \\
Productivity & Flexibility \\
Flexibility of labour market & Creativity \\
International embeddedness & Cosmopolitanism/Open-mindedness \\
Ability to transform. & Participation in public life \\
\hline Smart Governance (Participation) & Smart mobility (Transport and ICT) \\
\hline Participation in decision-making & Local accessibility \\
Public and social services & (Inter-)national accessibility \\
Transparent governance & Availability of ICT-infrastructure \\
Political strategies \& perspectives & Sustainable \\
& Innovative and safe transport systems \\
\hline Smart environment (Natural resources) & Smart living (Quality of life) \\
\hline Lack of pollution of natural conditions & Cultural facilities \\
Pollution & Health conditions \\
Environmental protection & Individual safety \\
Sustainable resource management & Housing quality \\
& Education facilities \\
& Touristic \\
\hline
\end{tabular}

Source: R. Giffinger, and G. Haindlmaier (2010) Smart cities ranking: an effective instrument for the positioning of the cities? ACE: Architecture, City and Environment, vol. 4, 12, pp. 7-26.

This concept, together with 74 indicators designed for all the aspects, includes data originating from Urban Audit, Espon and Eurostat databases. It significantly broadened the way of thinking on the directions of development for modern cities and major factors altering the contemporary urban environment (Stawasz, and Sikora-Fernandez, 2016). 
Thus, there is a number of different perspectives which are used for theoretical models of smart city. A conceptual confusion results also from the fact that this term is used for both modern settlements, artificially developed from scratch (such as New Songdo in the Republic of Korea, Masdar in the United Arab Emirates, and PlanIT in Portugal), and old cities where technology is seen as an instrument to improve the quality of life (Calzada, 2016).

\subsection{Social space and city smartness}

A heated discussion on the development of urban areas using ICT has been continued for almost two decades. It is accompanied by huge expenses provided for equipping cities with technologically advanced infrastructure and, somewhat less frequently, investment in the development of smart social capital (Holland, 2008).

The latest research shows that the acceleration of local and regional development is connected to innovations resulting from the field of Research \& Development, technological spillover, institutional mechanisms supporting education and innovation, as well as ICT-based knowledge management (Komnios, 2008, p. 23). New development models are based on spatial intelligence which combines three of its kinds: "the inventiveness, creativity and intellectual capital of the city's population; the collective intelligence of the city's institutions and social capital; and the artificial intelligence of public and city-wide smart infrastructure, virtual environments and intelligent" (Komnios, 2008, pp. 122-123). In this approach, development of cities and regions depends on the combination of three aspects of intelligence: human, collective, and artificial. A conclusion emerges that IT investment in cities only solve relevant urban problems if accompanied by development of social capital. Otherwise, social polarisation comes to existence, magnifying social inequalities that already exist (Holland, 2008).

Other modern concepts clarifying the issues of the development of urban spaces are based on percolation and synergy of various urban actors. The Triple Helix model depicts relationships between three groups of stakeholders: university, government and industry. It is believed that the layout formed of overlapping helix fields is more and more responsible for innovation. Industry acts as the source of production while government provides regulations, stability and principles, leaving the provision of technology and new knowledge to university (Galvão et al., 2017). In the smart city concept, the two following models are pointed out to more frequently: the Quadruple Helix model, and the Penta Helix model, which is the previous one with another helix added. A structure of the economy divided to four helixes breaks down to universities, industry, government and civil society, and their relationships generate innovation and economic growth. Penta Helix is a layout influencing smartness of the city/region by incorporating municipal actors and social entrepreneurs which provide the translation of practical knowledge to projects to be completed by industry. Urban regions are able to create new collaborative culture of citizen engagement (Calzada, and Cowie, 2017). What's worth pointing out is that huge amounts of data generated by each citizen and municipal institutions are taken into account here. If such data are made available, it may release enormous potential driving a variety of innovations, including the social ones. 
Table 2.

Frames for various helix models

\begin{tabular}{|l|l|l|l|}
\hline & \multicolumn{1}{|c|}{$\begin{array}{c}\text { Triple-Helix } \\
\text { (TH) }\end{array}$} & \multicolumn{1}{c|}{$\begin{array}{c}\text { Quadruple Helix } \\
\text { (QH) }\end{array}$} & \multicolumn{1}{c|}{$\begin{array}{c}\text { Penta-Helix } \\
\text { (PH) }\end{array}$} \\
\hline Multi-Stakeholders & $\begin{array}{l}\text { Public } \\
\text { Private } \\
\text { Academia }\end{array}$ & $\begin{array}{l}\text { Public } \\
\text { Private } \\
\text { Academia } \\
\text { Civic Society }\end{array}$ & $\begin{array}{l}\text { Public } \\
\text { Private } \\
\text { Academia } \\
\text { Civic Society } \\
\text { Social Entrepreneurs or } \\
\text { and Activists }\end{array}$ \\
\hline Paradigms & PPP & Civic Universities & Urban Commons \\
\hline $\begin{array}{l}\text { Governance Scheme \& } \\
\text { Citizenship Response }\end{array}$ & Invisible Citizenship & Reactive Citizenship & Proactive Citizenship \\
\hline Techno-Politics of Data & Technocratic Top-Down & $\begin{array}{l}\text { Institutionalised Bottom- } \\
\text { Up }\end{array}$ & $\begin{array}{l}\text { Emergent \& Complex } \\
\text { Bottom-Up }\end{array}$ \\
\hline
\end{tabular}

Source: Calzada, I and Cowie, P. (2017). Beyond smart and data-driven city-regions? Rethinking stakeholder-helixes strategies. Regions. The Voice of the Membership, Vol 308/ 4.

The Penta Helix model is compatible with a modern perception of the role of citizens in a smart city as many researchers believe that development is not possible without an active participation and incorporation of some citizens in the city management process (Shelton, and Lodato, 2019). The advantage to this model is the indication of new factors altering innovation architecture which, to a significant extent, depend on the efficient functioning of the society.

\subsection{Benchmarking miast}

The development of smart cities is continuously monitored in a global comparative perspective. For this purpose, there is a lot of various indicators measuring the primary areas selected by its creators, according to the assumed theoretical concept. They serve to support the development of urbanised areas by indicating the areas which require some intervention and by comparing with other cities in order to search for good practices.

One should note some expanded, cyclical rankings surveying cities in different continents (Table 3).

A disadvantage of such comparison, however, is a complete discrepancy of achieved results, caused by focusing on different indicators. Table 4 below shows three different city development rankings for 2018, collated together: Cities in Motion Index (CIMI), and Mercer Quality of Living, and Acardis - The Sustainable Cities Index. The first one, Cities in Motion Index (2018) includes city positioning based on nine major aspects: human capital, social integrity, economy, management, environment, mobility and transport, urban planning, international influence, and technology. It also points out to reliable sources providing necessary data, such as Euromonitor, World Bank, WHO, Yale University, and more. 


\section{Table 3.}

\section{Urban development indicators}

\begin{tabular}{|l|l|l|}
\hline Index & Arrangement \\
\hline Arcadis Sustainable Cities Index & 20 indicators in 3 subthemes \\
\hline Cities in Motion Index (CIMI) & 9 areas, 94 supporting indicators \\
\hline City Protocol 105 core, & 93 supporting indicators \\
\hline European Green Capital Award & 12 indicator areas with 4 qualitative descriptions each \\
\hline European Smart Cities & 6 key fields, 90 indicators \\
\hline IUME Integrated Urban Monitoring in Europe & 4 dimensions, 56 indicators \\
\hline Mercer Quality of Living & 10 areas, 39 indicators & \\
\hline Networked Society City Index & 2 perspectives, 6 dimensions, 15 variables, \\
\hline Siemens Green City Index & 35 indicators represented by 41 proxies & \\
\hline UNECE United Smart Cities & 30 indicators in 8 subthemes \\
\hline $\begin{array}{l}\text { ISO 37120 - Sustainable Development of } \\
\text { Communities - Indicators for City Services and } \\
\text { Quality of Life. }\end{array}$ & 46 indicators, 54 supporting indicators & \\
\hline $\begin{array}{l}\text { ISO 37122 - Sustainable Development of } \\
\text { Communities - Indicators for Smart Cities. }\end{array}$ & 19 areas, 75 indicators \\
\hline
\end{tabular}

Source: P. Bosch et al., (2017) Recommendations for the smart city index.

Another one, Mercer Quality of Living, performs measurements using ten basic aspects referring to cities:

- Political and social environment (political stability, crime, law enforcement, etc.);

- Economic environment (currency exchange regulations, banking services);

- Socio-cultural environment (media availability and censorship, limitations on personal freedom);

- Medical and health considerations (medical supplies and services, infectious diseases, sewage, waste disposal, air pollution);

- Schools and education (standards and availability of international schools);

- Public services and transportation (electricity, water, public transportation, traffic congestion, etc.);

- Recreation (restaurants, theatres, cinemas, sports and leisure);

- Consumer goods (availability of food/daily consumption items, cars);

- Housing (rental housing, household appliances, furniture, maintenance services);

- Natural environment (climate, record of natural disasters) (Mercer, 2018).

The third one, with relevance to sustainable development, The Sustainable Cities Index, rates three major fields and corresponding specific indicators:

- Social: personal well-being (health, education, crime), working life (income inequality, working hours, the dependency ratio), urban living (transport accessibility, digital services and other amenities),

- Environmental: immediate needs of citizens (water supplies, sanitation and air pollution), long-term impacts (energy consumption, recycling rates, greenhouse gas emissions), investment in low carbon infrastructure (renewable energy, bicycle 
infrastructure and electric vehicle incentives), city resilience (natural catastrophe exposure and risk monitoring).

- Economic: effectiveness of transport infrastructure (rail, air and traffic congestion), economic performance (GDP per capita, employment rates, ease of doing business, tourism, position in global economic networks), business infrastructure (mobile and broadband connectivity, employment rates and university technology research) (Acardis, 2018).

Table 4 shows a comparison of the charts referring to the smart city concept, the quality of life in cities, and sustainable development of urbanised areas. It can be noticed that each one presents a completely different hierarchy. Top ten cities in each ranking are described by different properties. The indicators used in CIMI rate large cities from Europe, and the Asia and Pacific region. The first four places are occupied by European centres, and places 4 to 9 , in turn, are taken by Tokyo, Singapore, Hong Kong, and Seoul, located in the Asia and Pacific region. The index confirms a good condition of European cities, their ability to deal with crisis, and general immunity to external and internal negative factors that highly urbanised areas face on a regular basis. The cities of Asia and the Pacific are powerful due to the strong economy based on modern technology, what balances a bit worse rating in the category of social integrity.

The measurement method suggested by Mercer Quality of Living demonstrates that none of the 10 cities qualified as the "smartest" is a city with a top quality of life. Top ten of this index includes mostly European cities, and compared with the cities in Motion Index, the Asian ones are missing here. Aside from European centres, top standings were given to: Auckland in New Zealand, Vancouver in Canada, and Sydney in Australia. Apart from the differences in geographical locations regarding continental belonging, the city's population was a significant criterion. Almost half of them are areas with low population. Three cities house a bit more than half a million (Vienna, Zürich, Vancouver), and one of them, Basel, is populated by less than 200,000. One can conclude that the general life conditions are somewhat better in Europe, particularly in cities with medium population, than in other regions of the globe.

\section{Table 4.}

World rankings of cities in 2018 according to Cities in Motion Index, Mercer Quality of Living, Acardis The Sustainable Cities Index

\begin{tabular}{|l|l|l|l|l|l|}
\hline & $\begin{array}{l}\text { Cities in Motion Index } \\
\text { (CIMI) }\end{array}$ & $\begin{array}{l}\text { Mercer Quality } \\
\text { of Living }\end{array}$ & $\begin{array}{l}\text { Acardis } \\
\text { The Sustainable } \\
\text { Cities Index }\end{array}$ \\
\hline 1. & New York - USA & 1. & Vienna - Austria & 1. & $\begin{array}{l}\text { London - United } \\
\text { Kingdom }\end{array}$ \\
\hline 2. & $\begin{array}{l}\text { London - United } \\
\text { Kingdom }\end{array}$ & 2. & Zürich - Switzerland & 2. & Stockholm -Sweden \\
\hline 3. & Paris - France & 3. & Munich - Germany & 3. & $\begin{array}{l}\text { Edinburgh -United } \\
\text { Kingdom }\end{array}$ \\
\hline 4. & Tokyo - Japan & 4 & $\begin{array}{l}\text { Auckland - New } \\
\text { Zealand }\end{array}$ & 4. & $\begin{array}{l}\text { Singapore - } \\
\text { Singapore }\end{array}$ \\
\hline
\end{tabular}


Cont. table 4.

\begin{tabular}{|l|l|l|l|l|l|}
\hline 5. & Reykjavik - Iceland & 5. & Vancouver - Canada & 5. & Vienna - Austria \\
\hline 6. & Singapore - Singapore & 6. & Düsseldorf - Germany & 6. & Zürich - Switzerland \\
\hline 7. & Seoul - South Korea & 7. & Frankfurt - Germany & 7. & Munich - Germany \\
\hline 8. & Toronto - Canada & 8. & Geneva - Switzerland & 8. & Oslo - Norway \\
\hline 9. & Hong Kong - China & 9. & $\begin{array}{l}\text { Copenhagen - } \\
\text { Denmark }\end{array}$ & 9. & Hong Kong - China \\
\hline 10. & $\begin{array}{l}\text { Amsterdam - } \\
\text { The Netherlands }\end{array}$ & 10. & $\begin{array}{l}\text { Bazel - Switzerland/ } \\
\text { Sydney - Australia }\end{array}$ & 10. & Frankfurt - Germany \\
\hline
\end{tabular}

Source: Cities in Motion Index, ISEE, 2018, https://media.iese.edu/research/pdfs/ST-0471-E.pdf.; Mercer Quality of Living, 2018, https://www.mercer.ch/newsroom/quality-of-living-2018.html, https://www.arcadis.com/en/global/our-perspectives/sustainable-cities-index-2018/citizen-centricities/.

The last ranking, Arcadis The Sustainable Cities Index, focuses on measuring three major areas: social, economic, and environmental. It indicates and compares the most sustainable urban environments. Most cities in the top ten can be found in the two previous lists (Figure 1). In the Arcadis ranking, there are three cities assessed positively by CIMI, and four selected by Mercer Quality of Living. Two capitals from the Scandinavian region were ranked high: Stockholm and Oslo. Another one with a high position was Edinburgh, Scotland. The results prove that the sustainable city category is broader, combining both smartness and the quality of life.

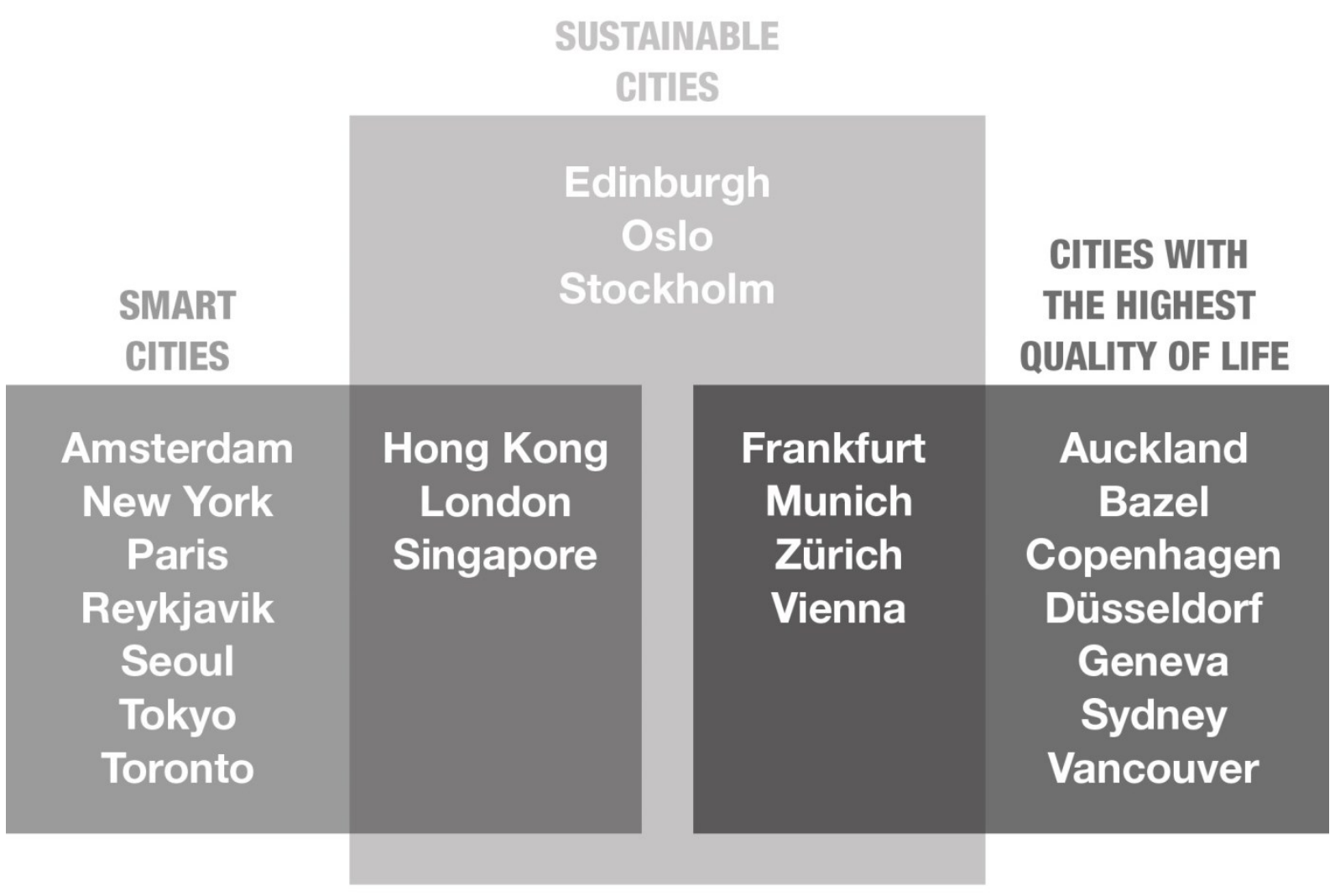

Figure 1. Comparison of urban hierarchy by CIMI, MERCER and ARCADIS. 


\section{Discussion}

Cities are not isolated technical systems, rather complex adaptive systems connecting towns and regions (Calzada, and Cobo, 2015). Therefore, the development of smart cities is considered in a broader sense as demonstrated by the rankings comparing different characteristics of urban centres. The result of the cities transforming to intelligent centres is the improvement in the quality of life (Komninos, 2018) as should be displayed by the indicators applied. No relation between the hierarchy formed in the smart city ranking and the top quality of life ranking suggests that technological solutions used in large metropolitan areas are not really relevant to the condition of residents' life. Strong focus on empowerment of urban citizenship, concentration on the actual needs of urban community (Shelton, and Lodato, 2019; Cardullo, and Kitchin, 2019) gradually redirects attention to the sustainability effect of urban space (Höjer, and Wangel, 2015). The future of cities will be affected not only by investment in smart systems but also by actions intending to protect the environment and to support social capital development.

As the rankings are published regularly, it helps monitor the directions of changes that occur in cities. Various indicators and research perspectives, measuring the functioning of cities, open new opportunities embedded in their resources. Therefore, it would bode well to create and apply indicators better adapted to the actual development conditions (Calzada, 2016). In result, it would allow for better conceptualisation of the city "smartness".

\section{Summary}

The smart city concept hides inside a promise of better life for everyone. It is assumed that connecting - thanks to the Internet - people, organisations, institutions, devices, machines and buildings, being included in urban sub-systems, will enable cost-effective power management, pollution reduction, and better resource management. More and more frequently, in city management the attention is paid to the idea that technology does not solve all problems, and investment in environment protection and strengthening urban communities results in the cities gaining a competitive advantage. Monitoring various city development rankings will allow concluding whether a smart city meets the global expectations for the improvement in the quality of life or whether it is merely a new form of neoliberal development of urbanised areas, supported by technology. 


\section{References}

1. Acardis (2018). Citizen Centric Cities The Sustainable Cities Index 2018. https://www.arcadis.com/en/global/our-perspectives/sustainable-cities-index-2018/citizencentricities/, 10.06.2019.

2. Bosch, P., Jongeneel, S., Neumann, H.M., Iglar, B., and Huovila, A. (2017). Recommendations for the smart city index. Retrieved from http://nws.eurocities.eu/ MediaShell/media/CITYkeys\%20D3.3\%20-\%20Recommendations\%20for\%20the\%20 Smart\%20City\%20Index.pdf, 11.06.1019.

3. Calzada, I., and Cowie, P. (2017). Beyond smart and data-driven city-regions? Rethinking stakeholder-helixes strategies. Regions. The Voice Of The Membership, 308(4), pp. 25-28. https://papers.ssrn.com/sol3/papers.cfm?abstract_id=3082935, 11.06.2019.

4. Calzada, I. (2016). (Un)Plugging Smart Cities with Urban Transformations: Towards Multistakeholder City-Regional Complex Urbanity? URBS, Revista de Estudios Urbanos y Ciencias Sociales Journal, 2. Retrieved from https://papers.ssrn.com/sol3/papers. cfm?abstract_id=2815957, 10.06.2019.

5. Calzada, I., and Cobo, C. (2015). Unplugging: Deconstructing the Smart City, Journal of Urban Technology, 2 (1), pp. 23-43. doi: 10.1080/10630732.2014.971535.

6. Caragliu, A., De Bo, C., and Nijcamp, P. (2009). Smart city in Europe. Journal of Urban Technology, 18(0048), pp. 45-69. doi: 10.1080/10630732.2011.601117.

7. Cardullo, P., and Kitchin, R. (2019). Being a 'Citizen' in the Smart City: Up and down the Scaffold of Smart Citizen Participation in Dublin, Ireland. GeoJournal, 84(1), pp. 1-13. doi.org/10.1007/s10708-018-9845-8.

8. Cities in Motion Index, ISEE (2018). https://media.iese.edu/research/pdfs/ST-0471-E.pdf.

9. Cities in Motion Index, ISEE (2019). https://media.iese.edu/research/pdfs/ST-0509-E.pdf.

10. Cowley R., Simon J., and Youri, D. (2018). The smart city and its publics: insights from across six UK cities. Urban Research \& Practice, 11(1), pp. 53-77. doi: 10.1080/ 17535069.2017.1293150.

11. Dameri, R. (2017). Smart City Implementation. Creating Economic and Public Value in Innovative Urban Systems. Retrieved from https://link.springer.com/content/pdf/ 10.1007\%2 F978-3-319-45766-6.pdf, 10.05.1019.

12. Dameri, R.P. (2013). Searching for smart city definition: A comprehensive proposal. International Journal of Computers \& Technology, 11(5), pp. 2544-2551. https://doi.org/10.24297/ijct.v11i5.1142.

13. Galvão, A., Mascarenhas, C., Rodrigues, R.G., Marques, C.S., and Leal, C.T. (2017). A quadruple helix model of entrepreneurship, innovation and stages of economic development. Review of International Business and Strategy, 27(2), pp. 261-282, doi.org/10.1108/RIBS-01-2017-0003. 
14. Giffinger, R., and Haindlmaier, G. (2010). Smart cities ranking: an effective instrument for the positioning of the cities? ACE: Architecture, City and Environment, 4(2), pp. 7-26. doi10.5821/ace.v4i12.2483.

15. Höjer, M., and Wangel, J. (2015) Smart Sustainable Cities: Definition and Challenges. In: L. Hilty and B. Aebischer (Eds.), ICT Innovations for Sustainability. Advances in Intelligent Systems and Computing, 310. Cham: Springer.

16. Hollands, R.G. (2008). Will the real smart city please stand up? City: Analysis of urban trends, culture, theory, policy, action, 12(3). pp. 303-320, http://dx.doi.org/10.1080/ 13604810802479126.

17. Komninos, N. (2002). Intelligent Cities: Innovation, Knowledge Systems and Digital Spaces. London: Spon Press.

18. Komninos, N. (2008). Intelligent Cities and Globalisation of Innovation Networks. LondonNew York: Routledge. Retrieved from http://www.stellenboschheritage.co.za/wp-content/ uploads/Intelligent-Cities-and-Globalisation-of-Innovation-Networks.pdf, 10.05.1019.

19. Komninos, N. (2018). Smart Cities. In: B. Warf (Ed.), The SAGE Encyclopedia of the Internet, 783-789. Sage Publications. doi: http://dx.doi.org/10.4135/9781473960367.n229, 06.06.2019.

20. Kummithaa, R.K.R., and Crutzenb, N. (2017). How do we understand smart cities? An evolutionary perspective. Cities, 67. pp. 43-52, doi.org/10.1016/j.cities.2017.04.010.

21. Kuźnik, F., and Baron, M. (2018) Użytkownicy miasta wobec smart city - studium prospektywne. Studia Ekonomiczne. Zeszyty Naukowe Uniwersytetu Ekonomicznego $w$ Katowicach, 365, pp. 63-77. http://cejsh.icm.edu.pl/cejsh/element/bwmeta1.element. cejsh-501d1868-086f-422a-a8d6-8baf4732a829, 17.07.2019.

22. Mercer Quality of Living (2018). https://www.mercer.com/newsroom/2018-quality-ofliving-survey.html, 10.06.2019.

23. Orłowski, C. (2014). Rule-based model for selecting integration technologies for smart cities systems. Cybernetics and Systems, 45(2), pp. 136-145. doi.org/10.1080/01969722. 2014.874811.

24. Shelton, T., and Lodato, T. (2019). Actually existing smart citizens. Expertise and (non)participation in the making of the smart city. City, 23(1), pp. 35-52. doi.org/10.1080/ 13604813.201.157511.

25. Stawasz, D., and Sikora-Fernandez, D. (2016). Koncepcja smart city na tle procesów i uwarunkowań rozwoju współczesnych miast. Łódź: Wyd. Uniwersytetu Łódzkiego.

26. WHO (2013). World Health Statistics 2013, http://www.who.int/gho/publications/ world_health_statistics/2013/en/, 07.06.2019.

27. Zuzańska-Żyśko, E. (2016). Procesy metropolizacji. Teoria i praktyka. Warszawa: PWN. 